\title{
Reset of Mg isotopic composition of limestone in late diagenesis
}

\author{
KAI XIANG ${ }^{1}$, BING SHEN ${ }^{1}$, TIANZHENG HUANG ${ }^{1}$ AND \\ CHAO LI $^{2}$ \\ ${ }^{1}$ Peking University \\ ${ }^{2}$ National research center for geoanalysis \\ Presenting Author: xiangkai@pku.edu.cn
}

The seawater magnesium $(\mathrm{Mg})$ isotopic composition $\left(\delta^{26} \mathrm{Mg}_{\mathrm{SW}}\right)$ can be applied to quantify the marine $\mathrm{Mg}$ cycle in Earth's history. Marine carbonate rocks have been widely used to reconstruct the deep time $\delta^{26} \mathrm{Mg}_{\mathrm{sw}}$ values. Nevertheless, it remains controversial whether carbonate recorded the primary seawater, because carbonate rocks have undergone a series of diagenetic alterations after deposition, such as aragonite-calcite transition, recrystallization, cementation et al. Thus, it is critical to evaluate whether the $\mathrm{Mg}$ isotopic compositions of carbonate $\left(\delta^{26} \mathrm{Mg}_{\text {carb }}\right)$ could be modified during diagenesis. In this study, we measured $\mathrm{Mg}$ isotopic composition of limestone samples from the Ordovician Liangiiasha Formation. The sampled section consists of alternating depositions of ribbon rock, i.e., alternate depositions of limestone and marlstone layers, and lime mudstone with partial recrystallization, i.e., microcrystalline calcite. $\delta^{26} \mathrm{Mg}_{\text {carb }}$ values range from -1.73 to -3.51 and $\mathrm{Mg} / \mathrm{Ca}$ ratios varies between 0.007 and 0.013 (molar ratio). The ribbon rock samples show a positive correlation between $\delta^{26} \mathrm{Mg}_{\text {carb }}$ and $\mathrm{K}$ or $\mathrm{Al}$ contents, while there is no correlation for the lime mudstone samples. Leaching experiment indicates that both $\mathrm{K}$ and $\mathrm{Al}$ can be washed by water, while $\mathrm{Mg}$ is released in acetic acid. Thus, samples with high clay contents or absorbed high $\mathrm{K}$ and $\mathrm{Al}$ would have higher $\delta^{26} \mathrm{Mg}_{\text {carb }}$ values. $\mathrm{K}$ and $\mathrm{Al}$ were mobilized from clay minerals in late diagenesis at relatively high temperature. Diagenetic clay modification would associate with the change of $\delta^{26} \mathrm{Mg}_{\text {carb }}$ via addition of ${ }^{26} \mathrm{Mg}$-enriched $\mathrm{Mg}$ probably from clays. Our study indicates that the $\mathrm{Mg}$ isotopic composition of argillaceous carbonate could be reset during diagenesis. These type of samples may not be suitable to reconstruct the deep time $\delta^{26} \mathrm{Mg}_{\text {carb }}$ values. 